\title{
The Impact of Consumer Product Package Quality on Consumption Satisfaction, Brand Perceptions, Consumer Investment and Behavior
}

\author{
Jeffrey S. Hess \\ California Polytechnic State University \\ jhess@.calply.edu \\ Lynn E. Metcalf \\ California Polytechnic State University \\ Imetcalf@calpoly.edu
}

\author{
Jay Singh \\ California Polytechnic State University \\ jasingh@calpoly.edu \\ Jeffrey Danes \\ California Polytechnic and State University \\ jdanes@calpolv.edu
}

\begin{abstract}
Consumer product packaging can serve a critical role in the consumption experience, but marketing and packaging science researchers focus primarily on pre and post-consumption aspects of consumer product containers. Exhaustive research into packing ergonomics, logistics, safety, sustainability and promotional features are common across marketing and packaging disciplines, but research isolating the role of a packaging in consumption satisfaction and enduring consumer-brand relationships is rare. In addition to an undervalued role in product satisfaction, functional isolation between marketing and packaging scientists limits packaging's overall impact on the bottom line.
\end{abstract}

This research examines the role of bottle quality in bottled-water consumption satisfaction and its subsequent impact on brand attribute perceptions, consumer-brand relationship investment and behavioral intentions. We show that thicker water bottles are perceived to be of higher quality than thinner bottles, and that these perceptual differences impact how customers view a brand on aspects such as reliability and value offered by the brand's products and ultimately intentions to re-purchase the brand's products.

We use qualitative, experimental and structural modeling analysis techniques to establish a fundamental role of packaging quality in consumer product satisfaction. We show that packaging characteristics are an indivisible component of the product and important to evaluation of the overall consumption experience. We finally conclude that packaging quality has a critical role to play in building profitable consumer-brand relationships, which should redefine the packaging cost-benefit equation to include the value of consumer loyalty as a balance to non-consumption packaging considerations.

Key Words: Package Quality; Water Bottle Quality; Consumer Brand Relationships; Customer Satisfaction, Consumer Investment, Product Quality 


\subsection{INTRODUCTION}

Packaging can serve an important role in the product consumption experience, but consumer product companies and researchers often focus on packaging's impact on product promotions, distribution and a range of pre-consumption and cost-based functions. Marketing and packaging literature often stratify the two disciplines in a way that may not accurately reflect the consumer experience. This marketing/packaging dichotomy isolates marketers and design/engineering decisionmakers and may have long-term negative impact on consumer-brand relationships ${ }^{1,2}$.

Packaging research often falls under two categories, each in conceptually isolated disciplines. Industrial technology research, often published in packaging-specific journals tends to focus on how physical package characteristics affect 1) distribution efficiency 2) shrinkage (i.e., product theft) 3) cost of materials 4 ) and usage. Azzi et al. ${ }^{3}$ propose a package design research framework that assigns consumer experience considerations a relatively minor role as compared to ergonomics, logistics, safety, sustainability and communication. Similarly, marketing-oriented packaging research emphasizes the promotional aspects of packaging, typically focusing on shelf appeal and label design. See [4 and 5] as representative examples.

This paper reports on a water bottle case study that emphasizes consumption effects of package design features as they impact product satisfaction and behavior. We first examine the role of packaging in the marketing value chain, then test a set hypotheses designed to isolate the impact of water bottle quality on brand perceptions and subsequent expectations of future purchase behavior.

The primary questions we attempt to address in this research are 1) whether the perceived quality of a consumable product's container directly impacts consumer evaluations of overall product quality and 2) whether package evaluations redound to consumer-brand relationship effects ${ }^{6,7,8}$.

\subsection{THE ROLE OF PACKAGE UTILITY IN BRAND VALUE}

Abbott ${ }^{9}$ describes at least four primary roles of consumer product packaging in the value chain; containment, protection, communication and utility. Product containment and protection serve discrete purposes and suggest a baseline of functional performance. Product communication informs consumers about package contents and facilitates the "first moment of truth" or product selection ${ }^{10}$. Measuring the effectiveness of containment, protection or even communication is relatively straightforward. Packaging either meets physical containment or protection standards or stimulates sales and complies with informational requirements.

Measuring the effectiveness of package utility, however, is more ambiguous. The ultimate arbiter of package utility is the consumer and the effectiveness of performance associated with utility, including ease of opening, consumption and disposa ${ }^{11}$ are best measured by the post-consumption attitudes or satisfaction they engender. This second moment of truth ${ }^{1,10}$ - the tactile experience with the package during the consumption - can have a profound impact on product evaluations and ${ }^{8}$ and consumer perceptions of brand value ${ }^{12}$. In other words, a successful second moment of truth makes another first moment of truth more likely.

Packaging fulfills a varied role in marketing from distribution to promotion, including shelf volume impact and visual appeal ${ }^{\text {c.f. } 1},{ }^{13}$ 
- 15. Marketing-oriented packaging research emphasizes transactional decision-making 16. However, in addition to stimulating purchase 2, 13, 17 packaging also communicates enduring brand characteristics that support brand loyalty ${ }^{17,18}$. Young ${ }^{2}$ even suggests that the future of packaging may include an expanded role in the consumption experience as it contributes to consumer-brand relationships and, recommending research on an expanded role in the marketing value chain ${ }^{1,19}$.

\subsection{WATER BOTTLE QUALITY AS A KEY EXPERIENCE INDICATOR}

Bottled water represents a product category in which the consumption experience is inextricably linked to the product's container. The product inside the bottle is limited in its ability to differentiate brands, but consumers are clearly able to discriminate preferences and identify favorite brands $^{20}$. The role of the bottle, and particularly the quality of the bottle is one potential factor contributing to brand preference. Furthermore, the nature of bottled water packaging dictates that many consumers will repeat their experience with a brand of water many times in a short timeframe, thus reinforcing consumption evaluations and their impact on profitable consumer-brand relationships ${ }^{6,21}$.

A trend toward thinner or "lightweighted" bottles suggests an implicit assumption that cost savings will offset negative consumer perceptions resulting from thinner gauge bottles, or that environmentally-focused messaging will offer a net benefit to brand perceptions. This strategy does suggest some risk, however, as product quality is the preeminent consideration in consumer product preference and longer-term brand relationships. In fact, perceived quality on a critical product char- acteristic can even inform consumer evaluations of other product features ${ }^{8,22}$. In this research, we focus on the quality of the bottle itself as a key determinant of the consumption satisfaction.

\subsection{CUSTOMER-BRAND RELATIONSHIPS AS A FUNCTION OF PRODUCT QUALITY}

The ultimate goal of consumer product brands is to develop enduring relationships with consumers ${ }^{23}$. Relationships are more profitable than disconnected transactions and imply a more efficient marketing cost benefit equation and offer some protection and idiosyncratic product failure and competitive activity 6,8,21,24. Consumer brand connections and associations are largely mediated by brand attributes reflective of experience and expected product performance, as well as by idiosyncratic personal connections to the brand ${ }^{24}$. Perceived benefit accrues to the consumer through direct assessment of brand and product characteristics and emotional rewards ${ }^{25}$. Expected functional and personal benefits combined with assessments of product value indicate a consumer's interest in long-term association with or investment in the brand ${ }^{26,27}$.

Product quality is a precursor to brand trust, the fundamental differentiator between enduring brand relationships and isolated consumer-brand transactions ${ }^{28,30}$. Product quality can reflect a response to a discrete consumption incident or reside as a cumulative construct resulting from a series of experiences ${ }^{30}$, but once established, transforms into beliefs about a brand's competence beyond evaluated attributes, or brand trust. Product performance and design are fundamental cues used by consumers to form long-term or committed relationships with brands 6, 31, 32. Consequently packaging quality has an important role to play 
in building brand trust that engenders consumer behaviors beyond simple repeat purchase, such as willingness to spend more on a brand's products ${ }^{30}$.

\subsection{DEVELOPMENT OF RESEARCH HYPOTHESES}

\section{Establishing Package Quality Differences (Manipulation Test)}

At the core of this research is a comparison of brand evaluations resulting from package quality differences, in this case differences reflected by the varying thickness of branded water bottles. Hypotheses H1-H4 test the proposition that water bottle thickness is a suitable surrogate for bottle quality by comparing quality perceptions of thick- and thin-gauge bottles. Qualitative descriptions provided an initial check of the manipulation and indicate thinner bottles are not only perceived to be lower in quality by subjects, but are also more likely to evoke negative descriptions of the consumption experience. Comments regarding the thin bottles were predominately negative $(24 \%$ vs. $76 \%$ ), focusing mainly on the quality of the bottle as it contributes to the consumption experience (e.g., Inability to stand it on a solid surface, perception of cheapness, ease of crumpling, cracking, caving in and collapsing during use). Positive comments focused on bottle recyclability rather than quality and usage features.

We hypothesize, therefore, that thicker gauge bottles will be perceived as higher quality and more user-friendly than thinner gauge bottles, thus supporting a more positively evaluated usage/consumption experience.

H1: Respondents will rate thick bottles higher on quality

$\mathrm{H} 2$ : Respondents will rate thick bottles higher on user-friendliness
H3: Respondents will rate thick bottles higher on ease of opening

H4: Respondents will rate thick bottles higher on ease of pouring

\section{Changes in Brand Perceptions and Preference Based on the Package Quality Difference:}

Product quality typically overwhelms other product characteristics in most consumer product brand evaluations ${ }^{33,34}$. We expect the bottled water category to reflect this emphasis on product quality over other considerations ${ }^{8,12}$. Consequently, we expect respondents to adjust their quality-related bottled water brand perceptions based on whether a brand of water they consume is associated with either thick or thin gauge water bottles. Furthermore, we predict that preference will follow a similar pattern. In contrast to all other ratings we expect perceptions of ecofriendliness will be positively associated with thin bottles. Specifically:

H5: Respondent ratings of brand reliability will increase for the thick bottle brand and decline for the thin bottle brand.

H6: Respondent perceptions of high quality plastic in bottles will increase for the thick bottle brand and decline for the thin bottle brand.

H7: Respondent ratings of "will likely purchase brand in next 30 days" will increase for the thick bottle brand and decline for the thin bottle brand.

H8: Respondent ratings of value for the money will increase for the thick bottle brand and decline for the thin bottle brand. 


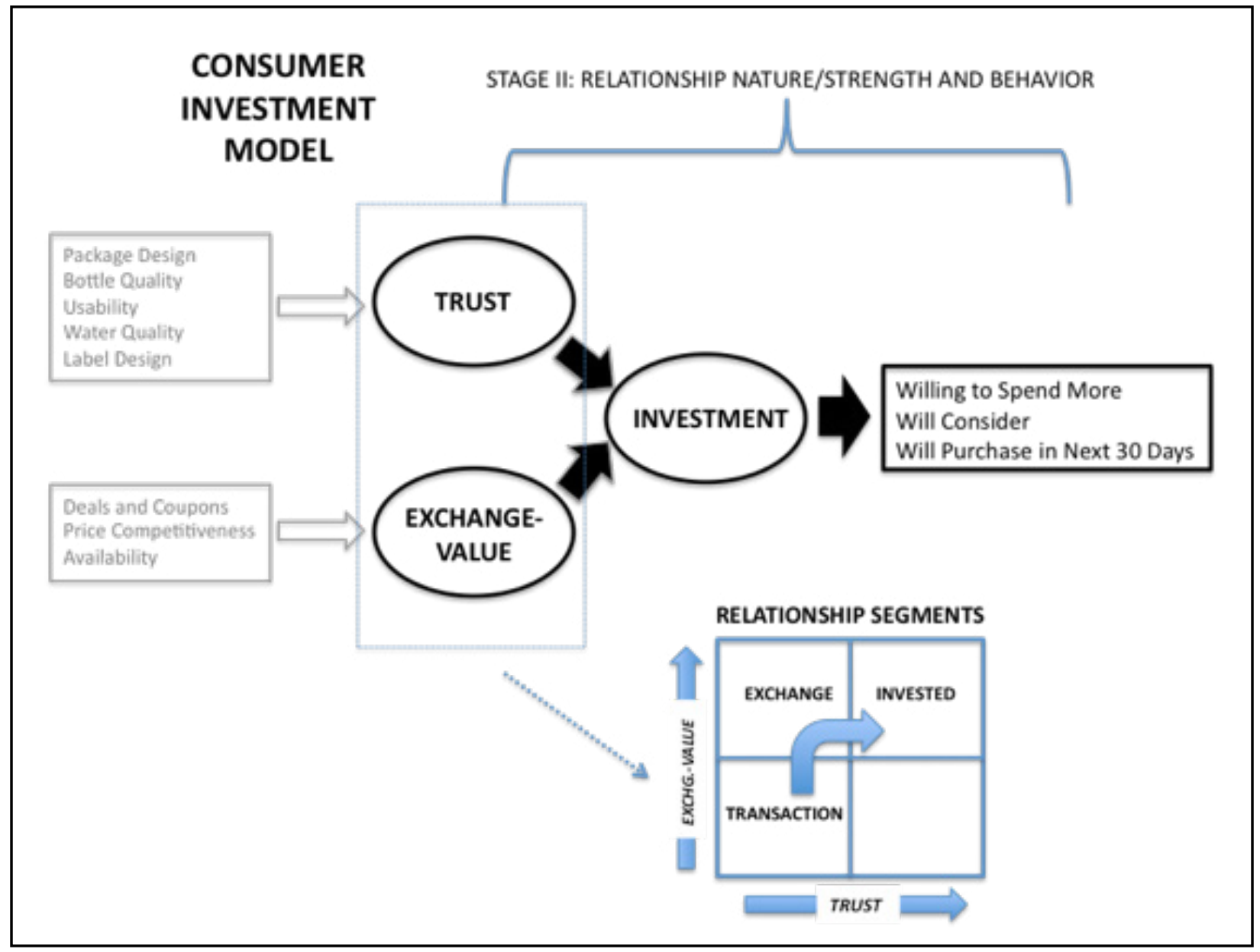

Figure 1

H9: Respondent ratings of eco-friendliness will decline for thick bottle brand and increase for the thin bottle brand.

\section{Impact of Consumption Experience on} Consumer-Brand Relationship Characteristics and Segment Membership

Consumer-brand relationships, and subsequent behavior, are ultimately determined by the accumulation of relational and economic benefit indicators ${ }^{6,27}$. Consumption experiences provide the most direct connection to expectations about future performance reflected in consumer trust in a brand and perceptions of brand value ${ }^{35}$. Together trust and value determine the strength (consumer commitment/investment) and nature (personal and functional) of consumer connections to a brand ${ }^{6}$. Invested customers should be willing to spend more for similar functional performance for brands with which they are motivated to continue a relationship $23,35,36$.

This is not a modeling-oriented research paper, but as a theoretical justification for the relationship segmentation comparisons we hypothesize that all structural paths in Stage II of the Relationship Investment model presented in Figure 1 will be significant (H10). 


\section{Relationship Typology and Segmentation}

While the strength and nature of consumer relationships are not independent, they each offer their own unique implications for marketing decisionmaking. Exchange-Value represents the primary differentiator between purely transaction-oriented customers and those who have a value-based relationship that leads to behavioral loyalty. Brand Trust transforms relationships built on ExchangeValue into Invested relationships, which are more profitable than either disconnected transactions or those reflecting mere behavioral loyalty [23]. Consumers can consequently be segmented based their evaluations of brand trust and exchangevalue, and their purchase behavior should reflect their segment membership. Specifically, we hypothesize attribute and behavioral expectation differences among three brand relationship segments: 1) a transactional group defined by low trust and exchange-value ratings, 2) a value-exchange relationship group defined by high exchange-value, but low trust ratings and 3) an invested group, defined by high exchange-value and trust ratings ${ }^{21}$.

\section{Direct Impact of Experimental Manipulation (Thin vs. Thick Consumption Treatment)}

H11 Respondents who were exposed to the thick version of the target brand's bottles will be more likely, than those exposed to thin bottles, to fall into the Invested (segment membership is mutually exclusive) segment.

\section{Brand Attribute Ratings}

H12 Brand bottle quality ratings will be higher for the Invested relationship segment than forthe Exchange relationship segment.
H13 There will be no significant difference on Eco-friendliness between Exchange and Invested relationship segments.

\section{Behavioral Intentions}

H14 Willingness to pay more will be higher for the Invested relationship segment than for the Exchange relationship segment.

H15 Intention to purchase in the next 30 days will be higher for Invested relationship segment than for the Exchange relationship segment.

\subsection{RESEARCH DESIGN}

This research is designed to isolate the effect of package quality on direct consumer evaluations of bottle water consumption, indirect brand attribute perceptions and bottled water brand relationship characteristics - the latter resulting in three relationship-type segments (transactional, exchange, invested). Each of four analytic methods reported below contributes to an overall thesis that the water bottle quality impacts short-term satisfaction as well as enduring brand relationships and purchase behavior of a bottled water brand's products.

The product brands and respondents were carefully chosen to be reflective of effects that can be projected to the general population. Specifically, 18-24 year old adults are about $8 \%$ more likely to drink bottled water than are average adults ${ }^{37}$. They are also more likely to drink Aquafina and Arrowhead, the central brands used in the study ${ }^{37}$. With respect to this category, young adults are sufficiently invested in this category to reflect real response to stimuli, and are projectable to additional segments of the population at large ${ }^{37}$. 
Two hundred and seventy-three subjects were screened for bottle water usage and their familiarity with the brands used in the study. They spent an average of $\$ 2.63$ per week on bottled water, and consumed an average of 3.6 bottles of water per week. Sixty-five percent of respondents purchased at least one bottle of water per week and fifty-nine percent of respondents said the quality of water they drink is "somewhat" or "very" important.

Subjects first completed an electronic survey that assessed their attitudes regarding the product category, familiarity with the top-selling brands of bottled water, brand perceptions and future brandrelated purchase intentions. They were then asked to consume water directly from bottles and describe their experience opening and drinking the water, in an open-ended fashion without direct prompting. During the time they were given to consume the water, they also completed pencil and paper survey for which they evaluated the qualities of the bottle and the water, as well as their overall experience consuming the water and purchase likelihood. Subjects finally completed a post-experience, electronic survey assessing perceived brand quality, relationship strength and behavioral intentions.

The study employed a mixed experimental design that included two bottle conditions (thin gauge and thick gauge bottles) for two brands (Arrowhead and Aquafina). We also included one non-branded thin vs. thick gauge cell in order to isolate bottle characteristics only. Table 1 identifies 11 cells across thickness and brand conditions into which participants were randomly assigned. Additional participants were added to the Aquafina-only cell (59 subjects) allowing for a direct comparison of bottle thickness, while controlling for brand effects in brand-related behavior comparisons. Aquafina was selected for this purpose as the only

\section{Experimental Cell Definitions}

\begin{tabular}{|c|c|c|}
\hline Brands vs. Brand - Identical Condition & $\begin{array}{c}\text { Arrowhead Thick } \\
\text { Aquafina Thick }\end{array}$ & $\begin{array}{c}\text { Arrowhead Thin } \\
\text { Aquafina Thin }\end{array}$ \\
\hline Brand vs. Brand - Unbalanced Condition & $\begin{array}{c}\text { Arrowhead Thick } \\
\text { Aquafina Thin }\end{array}$ & $\begin{array}{l}\text { Aquafina Thick } \\
\text { Arrowhead Thin }\end{array}$ \\
\hline Single Brand - Two Conditions & $\begin{array}{l}\text { Arrowhead Thick } \\
\text { Arrowhead Thin }\end{array}$ & $\begin{array}{l}\text { Aquafina Thick } \\
\text { Aquafina Thin }\end{array}$ \\
\hline \multirow[t]{2}{*}{ Single Bottle Cells } & Arrowhead Thick & Aquafina Thick \\
\hline & Arrowhead Thin & Aquafina Thin \\
\hline Unbranded & $\begin{array}{l}\text { Unbranded Thick } \\
\text { Unbranded Thin }\end{array}$ & \\
\hline
\end{tabular}

Table 1 


\begin{tabular}{|c|c|c|c|c|c|c|}
\hline User Friendly & $\frac{\frac{\text { Mean }}{\text { Diff. }}}{0.124}$ & $\frac{\text { Std. Dev. }}{1.449}$ & $\begin{array}{c}\begin{array}{c}\text { Std. } \\
\text { Error Mean }\end{array} \\
0.1\end{array}$ & ${ }_{1 .}^{\frac{\mathbf{t}}{241}}$ & $\frac{d f}{208}$ & $\frac{\text { Sig (1-tailed) }}{0.108}$ \\
\hline Ease of Pouring & 0.167 & 0.878 & 0.061 & 2.75 & 209 & 0.003 \\
\hline Bottle Quality & 0.441 & 1.577 & 0.109 & 4.061 & 210 & 0.001 \\
\hline Appealing Shape & -0.521 & 1.559 & 0.107 & -4.856 & 210 & 0.001 \\
\hline
\end{tabular}

Table 2

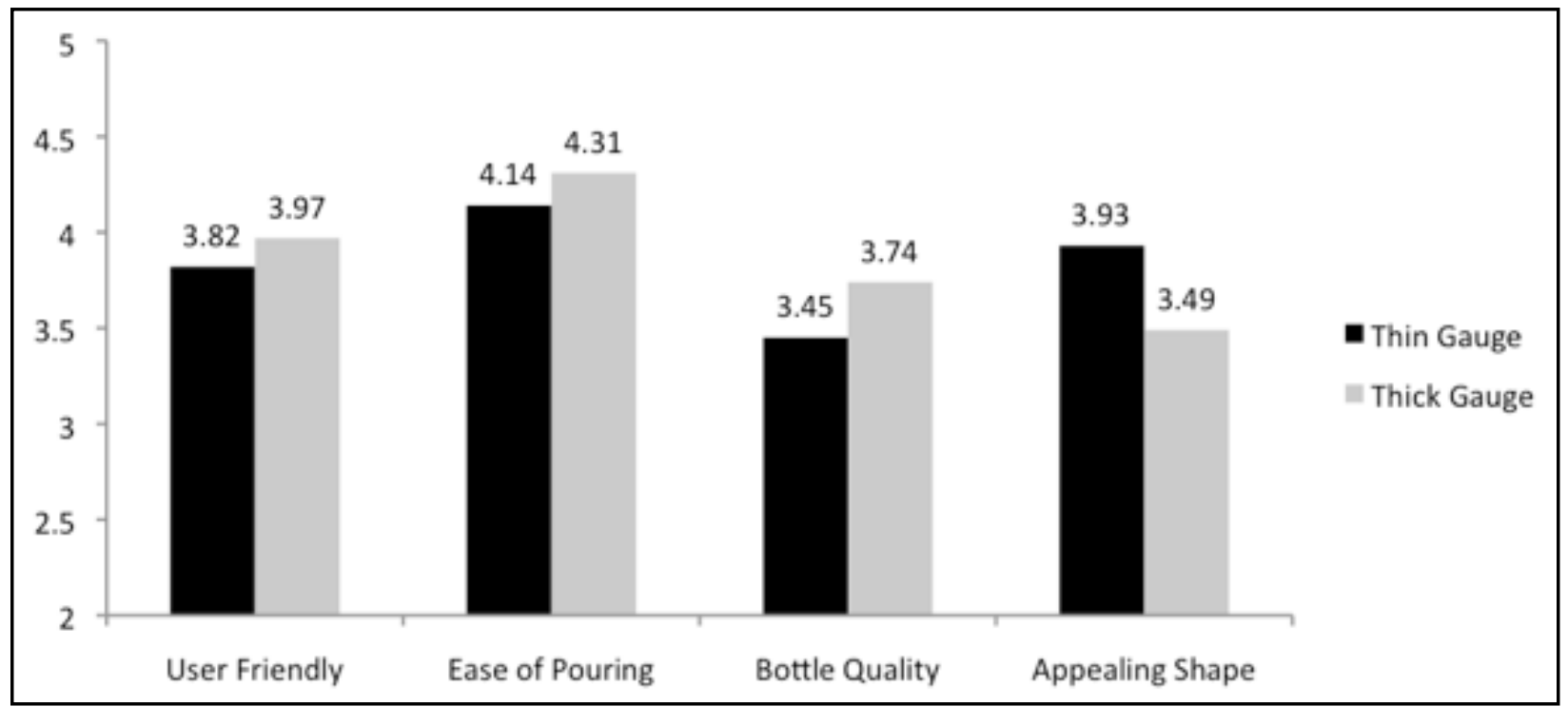

Figure 2

brand simultaneously offering both thin and thick bottles readily available on retail shelves.

\subsection{RESULTS: EXPERIENCE EVALUATIONS AND BRAND ATTRIBUTE CHANGES}

\section{Package Quality Differences (Manipulation Validity Check)}

Respondents were asked to consume a portion of either one or two bottles of water with no verbal or written indicators given as to bottle quality or thickness. Therefore, the first set of hypothesis tests regarding bottle quality functioned as a manipulation validity check, confirming that respondents perceived hypothesized quality differences between the thin and thick gauge bottles, independent of other evaluations such as visual appeal of the label and bottle shape. A comparison between unbranded thin and thick bottles was used for this purpose.

As reflected in Table 2 and Figure 2, thick bottles were perceived to be significantly higher in quality and easier to pour (mean differences $=0.44 / 0.17$ respectively) than thin bottles. User friendliness scores are higher for thick bottles also, but the difference is not statistically significant at the $95 \%$ confidence level. Thin bottles, however, did have 


\begin{tabular}{|c|c|c|c|c|c|}
\hline Attribute & $t$ & df & $\begin{array}{c}\text { Sig. } \\
\text { (1-tailed) }\end{array}$ & $\begin{array}{c}\text { Mean } \\
\text { Diff. }\end{array}$ & $\begin{array}{l}\text { Std. Error } \\
\text { Diff. }\end{array}$ \\
\hline Favorite Brand & -1.022 & 90 & 0.155 & -0.173 & 0.169 \\
\hline Reliable Brand & -1.127 & 90 & 0.133 & -0.174 & 0.155 \\
\hline Quality Bottles & -3.302 & 90 & $0.001 *$ & -0.561 & 0.170 \\
\hline Purchase in 30 Days & -1.813 & 90 & 0.037 & -0.375 & 0.207 \\
\hline Value for the Money & -2.415 & 90 & 0.009 & -0.398 & 0.165 \\
\hline Eco Friendly & 2.576 & 90 & $0.006 *$ & 0.441 & 0.171 \\
\hline
\end{tabular}

Table 3

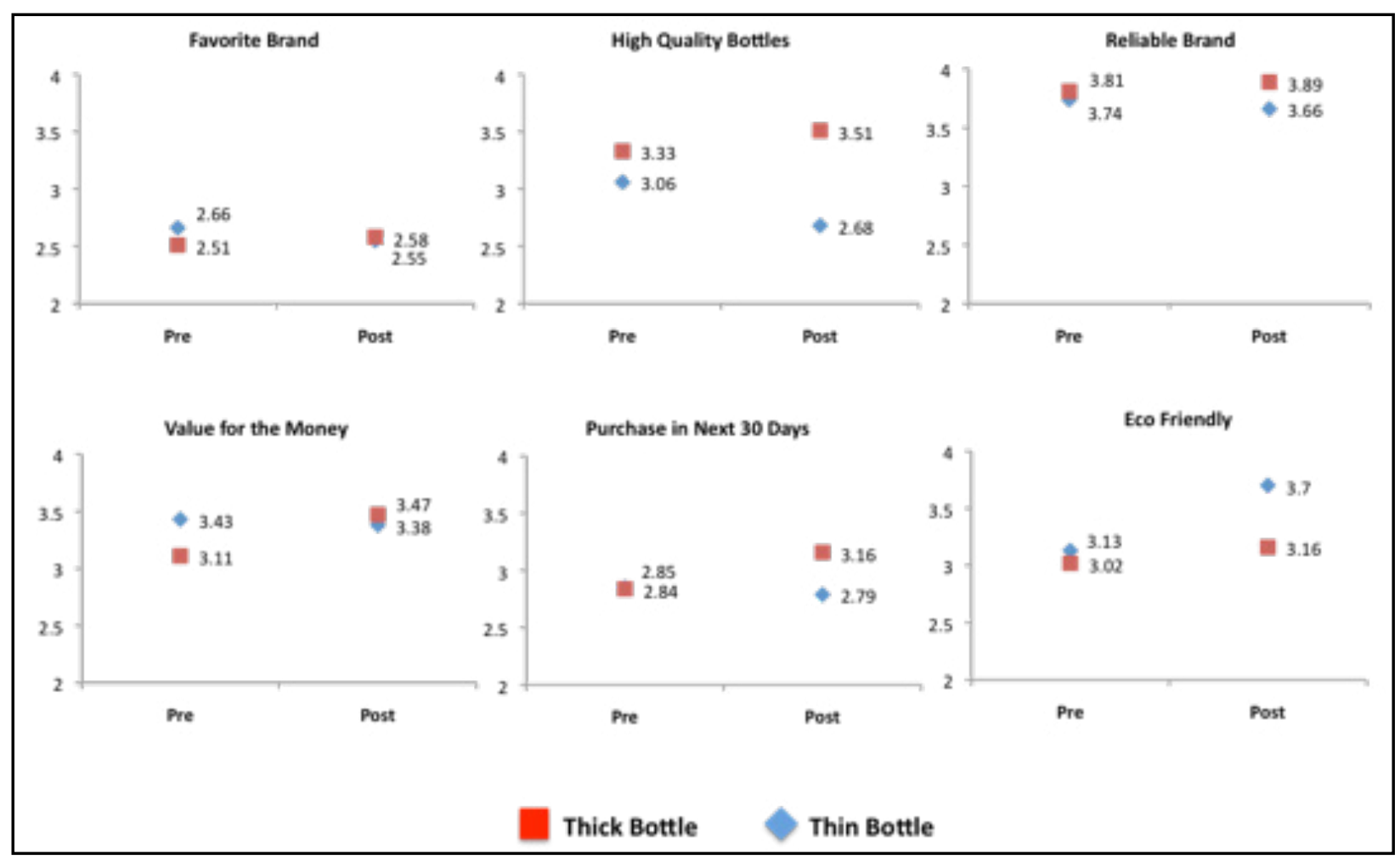

Figure 3

a significantly more appealing shape (mean difference $=.52$ ), suggesting a quality-shape paradox that may work to mitigate overall quality rating differences. One might even suggest respondents overcame a positive disposition toward the thinner bottles to give lower quality ratings.

\section{Brand Perception Changes in Response to} Package Quality Differences

We hypothesized that consuming water in a lower quality bottle would negatively impact evaluations of overall brand reliability and product 
quality and result in a negative impact on brand relationships and behavioral intentions. As reported in Table 3 and Figure 3, post manipulation ratings on brand bottle quality, value and intention to purchase in next 30 days and eco-friendliness all changed significantly in the hypothesized direction, but changes to 'favorite brand' and 'reliable brand' were not statistically significant according to a $95 \%$ confidence level criterion. These findings supports previous research indicating that quality and eco considerations are potentially in conflict with regard to consumer preference ${ }^{2,20}$, and that quality is the preeminent concern for consumers in most package good contexts ${ }^{33,37}$.

\subsection{RESULTS: THE IMPACT OF PACKAGE QUALITY ON CONSUMER BRAND RELATIONSHIPS}

\section{Consumer Investment Measurement Model and Causal Path Analysis}

Stage II of the bottled water consumer-brand relationship investment model ${ }^{6}$ includes fivemultiitem scales to measure bottled water brand trust, exchange value, investment, and revenue and profitability behavioral intention measures ${ }^{21}$. Following recommendations by Joreskog and Sorbom ${ }^{38}$ all scales were analyzed for validity and reliabil-

\section{Construct/Item (*Scale Reliabil
Brand Exchange-Value ( $\alpha=.772)$}

Aquafina offers a good value for the

money

I get what I pay for with Aquafina

Standardized

$\underline{\text { Estimate }}$

Brand Trust $(\alpha=.737)$

Aquafina is reliable

I know what to expect from Aquafina $\quad 0.862$

products

Brand Investment $(\alpha=.838)$

I choose Aquafina over other brands

Aquafina is my favorite brand

(*Chronbach's alpha)

Table 4 
ity and meet acceptable requirements for internal consistency. Table 4 reports all scale reliabilities and included and deleted items. Scale reliabilities ranged from .74 (Trust) to .84 (Investment).

The Model shown in Figure 1 was estimated using AMOS 16, a structural equation modeling program that allows us to simultaneously test the overall fit of the model and the strength of all individual paths among constructs and observed variables. The loading for one indicator of each construct was fixed at 1.0 and the exogenous variables were allowed to correlate freely. As reflected in Table 5 Most commonly used fit indices indicate a reasonably well-fitting model [39] with $\mathrm{X} 2=30.306$ with $17 \mathrm{df}, \mathrm{p}=.022$; CFI $=.986$, NFI $=.970$, PNFI .589 and RMSEA $(90 \% \mathrm{CI})=.060$. The PNFI [40], which attempts to account for the complexity of the model, reflects the fact that this is a relatively simple model, focused on investment process outcomes. An excellent RMSEA ${ }^{41}$ suggests the model fits well given its simplicity. All paths are significant at the $\mathrm{p}>.001$ level as predicted by H11.

\section{Component Structure Tests and Relationship Segment Comparison}

Story and Hess [7] describe a construct scorebased group classification scheme that includes at least three relationship type groups. They label consumer segments as Invested (high on Exchange-Value and Trust), Exchange (High on Exchange-Value only) and Transactional (High on neither). As recommended by Story and Hess, we classify ratings of 4 and 5 (on a 5-point scale) as "high" on Exchange-Value and Trust. Table 6 reports mean comparisons for the Exchange Relation-

\begin{tabular}{|c|c|c|c|}
\hline Hypothesized Causal Path & $\underline{\text { Std. Estimate }}$ & C.R. & p-value \\
\hline Brand Trust > Investment & 0.306 & 3.379 & $<.001$ \\
\hline Brand Exchange-Value $>$ Investment & 0.481 & 5.286 & $<.001$ \\
\hline Investment > Will Spend More on Brand & 0.833 & 15.599 & $<.001$ \\
\hline Investment > Will Consider Brand & 0.786 & 13.975 & $<.001$ \\
\hline $\mathrm{CFI}=.986$ & $\mathrm{X} 2=30.573$ & & \\
\hline $\mathbf{N F I}=.970$ & $d f=17$ & & \\
\hline $\mathrm{PNFI}=.589$ & $p=.022$ & & \\
\hline RMSEA $=.060$ & & & \\
\hline
\end{tabular}

Table 5 


\begin{tabular}{|lcccccc|}
\hline & $\begin{array}{c}\text { Mean } \\
\text { Invested }\end{array}$ & $\begin{array}{c}\text { Mean } \\
\text { Exchange }\end{array}$ & $\begin{array}{c}\text { Mean } \\
\text { Diff. }\end{array}$ & $\underline{\underline{\text { df }}}$ & $\underline{\text { Sig (1-tailed) }}$ \\
Investment & 3.71 & 2.89 & 0.82 & 79 & $\mathrm{p}<0.001$ \\
Exchange & 4.03 & 3.71 & 0.32 & 79 & $\mathrm{p}=0.002$ \\
High Quality Bottles & 3.94 & 3.53 & 0.41 & 79 & $\mathrm{p}=0.005$ \\
Eco-Friendly & 3.56 & 3.45 & 0.11 & 79 & $\mathrm{p}=0.415$ \\
Will Spend More & 3.66 & 2.72 & 0.94 & 79 & $\mathrm{p}<0.001$ \\
Will Consider & 4.28 & 3.75 & 0.53 & 79 & $\mathrm{p}=0.002$ \\
\hline
\end{tabular}

Table 6

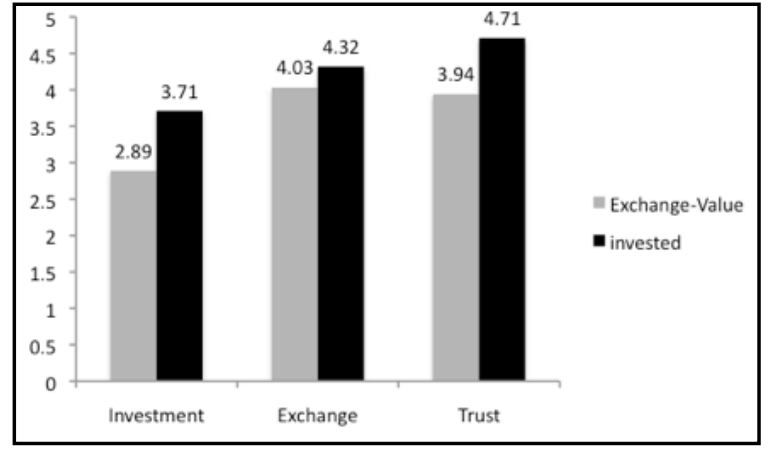

Figure 4

ship segment (high Exchange-Value only) vs. Invested Relationships (high Exchange-Value and Trust).

As predicted consumer Investment is higher in the Invested segment, which is defined by high Trust and Exchange-Value, supporting the idea that trust is the primary differentiator between relationships that exhibit consumer investment and those that do not.

Hypotheses 14 and 15 address differences in relationship segment characteristics due to differences in perceived bottle quality. As hypothesized, there is a significant difference between brand bottle quality ratings for Invested and Exchange segments (diff. $=.41, \mathrm{p}=.005$ ), but no significant difference in eco-friendliness ratings (diff.

$$
=.11, \mathrm{p}=.415) \text {. }
$$

We also predicted that behavioral intentions

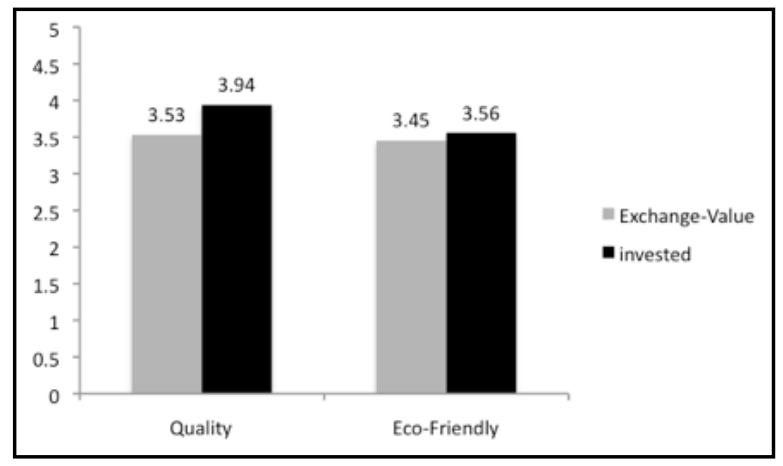

Figure 5

will be significantly different between Invested and Exchange segments. Differences between the relationship segments on consideration (diff. $=.53, \mathrm{p}$ $=.001$ ) and willingness to spend more (diff. $=.94$, $\mathrm{p}=.002$ ) on the brand are both significant, but the difference on willingness to spend more is nearly double that of consideration. Supporting previous research that suggests behavioral differences among exchange and invested consumers are most pronounced on behaviors indicative of profitable consumer behaviors, and less pronounced on those that merely reflect sales volume ${ }^{6,32,35}$. 


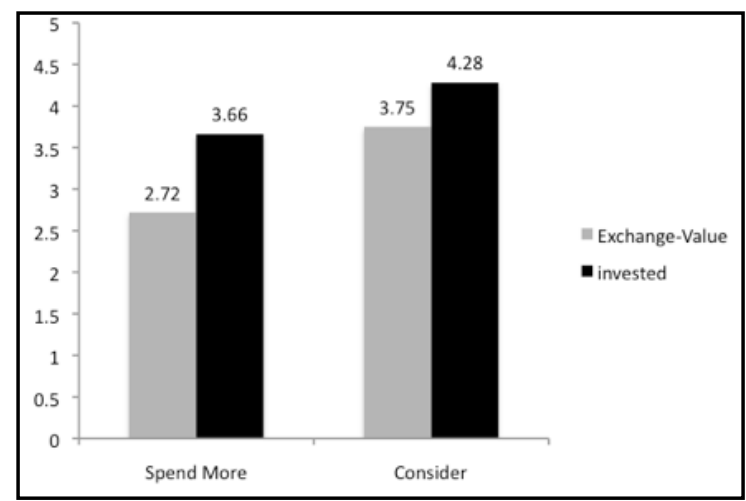

Figure 6

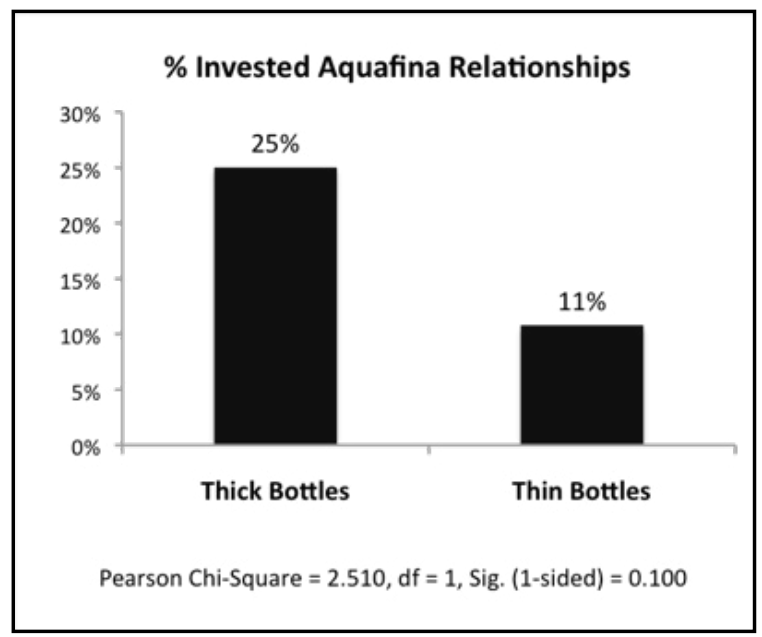

Figure 7

Perhaps the most challenging hypothesis is $\mathrm{H} 12$, which proposes segmentation as a function of the bottle quality manipulation. The difference in likelihood of falling into the Invested segment vs. the Exchange segment was not significant at the 95\% confidence interval (See Figure 7); however, the difference would be significant at the $90 \%$ confidence interval, which suggests sample size constrained this effect, thus warranting further investigation.

\subsection{SUMMARY AND CONCLUSION}

Packaging serves a critical role in marketing and, in some product categories, such as bottled water the container carrying the consumable is inextricably linked to the consumption experience itself. In that role the bottle, and more specifically the quality of the bottle, potentially represents a key determinant to producing enduring profitable consumer-brand relationships. This paper bridges packaging researchers' emphasis on physical container characteristics and marketing researchers' focus on communication aspects of packaging by focusing on the shared goals implicit in package utility ${ }^{9}$. This research demonstrates how the quality of a water bottle impacts post-consumption experience evaluations $(\mathrm{H} 1-\mathrm{H} 4)$, brand evaluations and subsequent behavioral intentions (H5-H9). As a result, packaging is a fundamental element in building and supporting enduring consumerbrand relationships (H11-H15) and profitability. The research presented here supports the thesis that specific performance evaluations - based on bottle design, quality and usability - help determine strength and nature of consumer-brand relationships, supporting the idea that packaging is a critical link in the consumer product value chain.

\subsection{LIMITATIONS AND IMPLICATIONS FOR FUTURE RESEARCH}

As primary or laboratory research, we acknowledge the limitations in projecting individual experience phenomena to broad consumption experiences. We believe, however, that this research establishes that the consumer's experience and subsequent brand evaluations are directly impacted by the quality of a product's container. We also understand the nature of the relationship between the package and the product with regard to the consumption experience is category dependent. We, therefore, suggest future research should address the contextual boundaries of these research findings. Specifically, we expect the temporal relationship between package interface 
and product consumption to moderate the role of packaging in consumption satisfaction. The theoretical constructs and processes described by cue utilization research [42], [43], for instance, suggest a framework in which the relationship between intrinsic and future quality expectations are derived via extrinsic cues.

A primary contribution of this work is the implication that, unless research acknowledges the important role of packaging in the value chain it shortchanges packaging's contribution to profitable consumer-brand relationships. As a result, we recommend expansion of research into the consumption characteristics of packaging toward identification of specific package quality consumption cues across product categories and by package function. For instance, in the frozen food category the container is often integral to food preparation, suggesting that food safety perceptions and the efficacy (traits indicated by brand trust) of the container in food preparation is important to satisfaction and preference. Also, this data suggest that marketing and packaging research collaboration will result in a more robust understanding of the impact of physical package characteristics on attitudinal and relational outcomes. Finally, this research advocates expanded investigation into how functional and organizational structures either mitigate or support collaboration between marketing professionals and package engineers toward fully elaborated package value creation.

\section{REFERENCES}

[1] Löfgren M, Witell L, Gustafsson A. "Customer satisfaction in the first and second moments of truth," Journal of Product and Brand Management, vol. 17, (7) pp. 463-474, 2008. Link
[2] Young S. "New and improved indeed: documenting the business value of packaging innovation," Quirk's Marketing Research Review, vol. 22, (1) pp. 46-50, 2008.

[3] Azzi A, Battini D, Persona A, Sgarbossa F. "Packaging design: general framework and research agenda," Packaging Technology and Science, vol. 25, (8) pp. 435-456, 2012. Link

[4] Ampuero O, Vila N. "Consumer perceptions of product packaging," Journal of Consumer Marketing, vol. 23, (2) pp. 102-114, 2006. Link

[5] Underwood R, Klein N. "Packaging as brand communication: Effects of product pictures on consumer responses to the package and brand," Journal of Marketing Theory and Practice, vol.10, (4) pp. 58-68, 2002. Link

[6] Hess J, Story J, Danes J. "A three-stage model of consumer relationship investment," Journal of Product \& Brand Management, vol. 20, (1) pp. 14 - 26, 2011. Link

[7] Story J, Hess J. "Ethical brand management: customer relationships and ethical duties," Journal of Product \& Brand Management, vol. 19, (4) pp. 240-249, 2010. Link

[8] Underwood R. "The communicative power of product packaging: Creating brand identify via lived and mediated experience," Journal of Marketing Theory and Practice, vol. 11, (1) pp. 6276, 2003. Link

[9] AbbottD.A.PackagingPerspectives,Dubuque, Kendall/Hunt Publishing Co., 1989. 
[10] Singh S P, Singh J, Grewal G, Chonhenchob V. "Analyzing color on printed packaging to evaluate brand logo integrity and impact on marketing," Universal Journal of Marketing and Business Research, vol. 1, (3) pp. 79-88, 2012. Link

[11] Singh S P, and Singh J. "Pictorial markings and labels for safe transport and handling of packaged goods," Journal of Packaging Technology and Science, vol. 18, (3) pp. 133-140, 2005. Link

[12] Esch F, Moll T, Schmitt B, Elger C, Neuhaus C, Weber B. "Brands on the brain: Do consumers use declarative information or experienced emotions to evaluate brands?" Journal of Consumer Psychology, vol. 22, (1) pp. 75-85, 2012. Link

[13] Connolly A, and Davison L. "How does design affect decisions at point of sale?" Journal of Brand Management, vol. 4, (4) pp. 100-107, 1996. Link

[14] Gofman A, Moskowitz H, Mets T. "Accelerating structured consumerdriven package design," Journal of Consumer Marketing, vol. 27, (2) pp. 157-168, 2012. Link

[15] Silayoi P, Speece M. "The importance of packaging attributes: a conjoint analysis approach," European Journal of Marketing, vol. 41, (11-12) pp. 1495 - 1517, 2007. Link

[16] Wells L, Farley H, Armstrong G. "The importance of packaging design for ownlabel food brands," International Journal of Retail \& Distribution Management, vol. 35, (9) pp. 677-690, 2007. Link
[17] Bloch P, Brunel F, Arnold T. "Individual differences in the centrality of visual product aesthetics: concept and measurement," Journal of Consumer Research, vol. 29, (4) pp. 551-565, 2003. Link

[18] Karjalainen T, Snelders D. "Designing visual recognition for the brand," Journal of Product Innovation Management, vol. 27, (1) pp. 6-22, 2009. Link

[19] Moskowitz H, Rabino S, Beckley J. "Concept articulation and web research: a case study using quali-quant methods," Qualitative Market Research: An International Journal, vol. 10, (3) pp. 282-299, 2007. Link

[20] Metcalf L, Hess J, Danes J, Singh J. “A mixed-methods approach for designing market-driven packaging," Qualitative Market Research: An International Journal, vol. 15, (3) pp. 268-289, 2012. Link

[21] Story J, Hess J. "Segmenting consumerbrand relations: beyond the personal relationship metaphor," Journal of Consumer Marketing, vol. 23, (7) pp. 406-413, 2006. Link

[22] Aaker D, Keller K. "Consumer evaluations of brand extensions," Journal of Marketing, vol. 54, (1) pp. 27-41, 1990. Link

[23] Morgan R, Hunt S. "The commitmenttrust theory of relationship marketing," Journal of Marketing, vol. 58, (3) pp. 20-38, 1994. Link

[24] Aaker D. Managing Brand Equity, New York: The Free Press, 1990.

[25] Thye S, Yoon J, Lawler E. "The theory of relational cohesion: review of a research," Advances in Group Processes, vol. 19, pp. 139-166, 2002. Link 
[26] Rusbult C. "Commitment and satisfaction in romantic associations: a test of the investment model," Journal of Experimental Social Psychology, vol.16, pp. 172-186, 1980. Link

[27] Rusbult, C. "A Longitudinal test of the investment model: the development (and deterioration) of satisfaction and commitment in heterosexual involvements," Journal of Personality and Social Psychology, vol. 45, (1) pp. 101-117, 1983. Link

[28] Delgado-Ballester E, Munuera-Aleman L. "Brand trust in the context of consumer loyalty," European Journal of Marketing, vol. 35, (11-12) pp.12381258, 2001. Link

[29] Garbarino E, Johnson S. "The different roles of satisfaction, trust, and commitment in customer relationships," Journal of Marketing, vol. 63, (2) pp. 70-87, 1999. Link

[30] Sirdeshmukh D, Singh J, Sabol B. "Consumer trust, value, and loyalty in relational exchanges," Journal of Marketing, vol. 66, (1) pp. 15-37, 2002. Link

[31] Hess J, Story J. "Trust-based commitment: multidimensional consumer-brand relationships," Journal of Consumer Marketing, vol. 22, (6) pp. 313-22, 2005. Link

[32] Fournier S. "Consumers and their brands: developing relationship theory in consumer research," Journal of Consumer Research, vol. 24, (2) pp. 343-373, 1998. Link

[33] Zeithaml V. "Consumer perceptions of price, quality, and value: a means-end model of synthesis and evidence," Journal of Marketing, vol. 52, (2) pp. 2-22, 1988. Link
[34] Stizhakova Y, Coulter R, Price L. "Branding in a global marketplace: The mediating effects of quality and self-identity brand signals," International Journal of Research in Marketing, vol. 28, (4) pp. 342-351, 2011. Link

[35] Hess J and Story J. "Trust-based commitment: multidimensional consumer-brand relationships," Journal of Consumer Marketing, vol. 22, (6) pp. 313-22. Link

[36] Sheth J, Parvatiyar A. "Relationship marketing in consumer markets: antecedents and consequences," Journal of the Academy of Marketing Science, vol. 23, (4) pp. 255-271, 1995. Link

[37] GfK Mediamark Research \& Intelligence. Fall 2011 Product beverage report. GfK MRI Reporter.

[38] Jöreskog K, Sörbom D. LISREL 7: A Guide to the Programs and Application, 2d. ed. Chicago: SPSS Inc., 1989.

[39] Savalei V, Bentler P M. "Structural equation modeling," in The Handbook of Marketing Research: Uses, Misuses, and Future Advances, Grover, R. and Vriens, M., Eds. Thousand Oaks: Sage Publications, 2006, pp. 330-364. Link

[40] James L, Mulaik S, Brett J. Causal Analysis: Models, Assumptions and Data, BeverlyHills: Sage Publications, 1982.

[41] Hair J, Black W, Babin B, Anderson R, Tatham R. Multivariate Data Analysis, 6d. ed. Upper Saddle River: Pearson Prentice Hall, 2006.

[42] Bredahl L. "Cue utilization and quality perception with regard to branded beef," Food Quality and Science, vol. 15, (1) pp. 65-75, 2004. Link 
[43] Woodside A. "Consumer evaluations of competing brands: Perceptual versus predictive validity," Psychology and Marketing, vol. 29, (6) pp. 458-466, 2012. $\underline{\underline{\text { Link }}}$ 